\title{
Equipments to manage soil and irrigated rice straw for the sequential sowing of soybean in tropical floodplains ${ }^{1}$
}

\author{
José Geraldo da Silva ${ }^{2}$, Adriano Stephan Nascente ${ }^{2}$, Pedro Marques da Silveira ${ }^{2}$
}

\section{ABSTRACT}

The presence of straw hinders the sowing of soybean cultivated in succession to rice, in areas irrigated by flooding. This study aimed to evaluate the combination of different configurations of a rice harvester and subsequent activities in the operational and energetic demand of rice straw management and in the soil surface roughness, in order to cultivate soybean in succession. Three independent experiments were conducted in a completely randomized design, as well as evaluated the fuel consumption, effective operating speed, working capacity and final surface roughness of the ground. The energy costs of harvesting rice do not increase when the automated harvester operates with a spreader to distribute the straw on the ground and to avoid the formation of furrows. The presence of rice plant residues in the field increases the skidding of the tractor when pulling the knife-roller, with a consequent reduction of the operating speed, but this does not affect the operational capacity and the fuel consumption. The increase in the number of light harrowings, from one to two operations, in areas worked with knife-roller or intermediate harrow, requires more time and fuel in the management of the soil and rice straw, but leaves the ground with less surface roughness. The management system with knife-roller operation and two light harrowings is the most appropriate method to prepare the soil for soybean cultivation after rice, because it provides the best combination of technical and energetic performance.

KEYWORDS: Soil preparation, soil surface roughness, vegetation cover, fuel consumption.

\section{INTRODUCTION}

The potential area for irrigation in the Brazilian floodplain ecosystem (FLOODE) in the tropical environment is estimated at 15 million ha (Coelho et al. 2006). The Tocantins state has the largest planted area of rice in this environment $(120,000 \mathrm{ha})$ and a potential area of 1.0 million ha in

\section{RESUMO}

Equipamentos para manejo de solo e palha de arroz irrigado visando à semeadura sequencial de soja em várzeas tropicais

A presença de palha dificulta a semeadura de soja cultivada em sucessão a arroz, em áreas irrigadas por inundação. Objetivouse avaliar a combinação de configurações de colhedora de arroz e operações subsequentes na demanda operacional e energética do manejo da palha de arroz e na rugosidade superficial do solo, visando ao cultivo da soja em sucessão. Foram conduzidos três experimentos independentes, em delineamento inteiramente casualizado, e avaliados o consumo de combustível, a velocidade operacional efetiva e a capacidade de trabalho, bem como a rugosidade superficial final do terreno. Os gastos energéticos na colheita do arroz não se elevam quando a colhedora automotriz opera com espalhador para distribuir a palha sobre o terreno e evitar a formação de leiras. A presença de restos de plantas de arroz na lavoura eleva o patinamento do trator no tracionamento do rolo-faca, com consequente redução da velocidade operacional, mas isso não afeta a capacidade de trabalho e o consumo de combustível. O aumento do número de gradagens leves, de uma para duas operações, em áreas trabalhadas com rolofaca ou com grade intermediária, demanda mais tempo e combustível no manejo do solo e da palha de arroz; porém, deixa o terreno com menos rugosidade superficial. O sistema de manejo com rolo-faca e duas gradagens leves é o método mais adequado para preparar o solo para o cultivo de soja em sucessão a arroz, pois proporciona a melhor combinação de desempenho técnico e energético.

PALAVRAS-CHAVE: Preparo do solo, rugosidade superficial do solo, cobertura vegetal, consumo de combustível.

the Tocantins-Araguaia Valley (Fragoso et al. 2013). In Tocantins, rice is cultivated in the rainy season, in a flood irrigation system, and then, in $80 \%$ of this area, soybean is cultivated in succession during the dry season, with irrigation (Conab 2018). Thus, in the off-season, the absence of rainfall, combined with a low relative humidity and low nighttime temperature, decreases the disease incidence and is

1. Received: Sep. 11, 2018. Accepted: May 02, 2019. Published: Jul. 19, 2019. DOI: 10.1590/1983-40632019v4954879.

2. Empresa Brasileira de Pesquisa Agropecuária (Embrapa Arroz e Feijão), Santo Antônio de Goiás, GO, Brasil. E-mail/ORCID: josegeraldo.silva@embrapa.br/0000-0002-6817-204X, adriano.nascente@embrapa.br/ 0000-0002-6014-3797, pedro.silveira@embrapa.br/0000-0002-2348-0305. 
used by soybean producers to obtain good quality seeds (Pelúzio et al. 2008).

The intensive use of FLOODE areas with flooded rice and soybean in the off-season requires the adequate postharvest management of the rice crop, in order to allow the soybean sowing at the appropriate time (it is recommended the month of May). This postharvest management of rice straw involves the removal of tracks left by the crop harvester and grain transport equipment, as well as the handling of rice crop residues. Straw is the part of the rice plant left on the ground after harvest (Santos et al. 2017). The amount of straw produced by rice cultivars is, on average, similar to the quantity of grains, ranging from $7 \mathrm{Mg} \mathrm{ha}^{-1}$ to $10 \mathrm{Mg} \mathrm{ha}^{-1}$ (Santos et al. 2006).

The presence of large amounts of rice straw causes operational difficulties, requiring the soil preparation for the sowing of species in succession to flooded rice, such as soybean. Many producers do not incorporate flooded rice straw and burning is common, what is facilitated by the furrows formed by rice harvesters without a chopper or straw spreader. However, to achieve a greater efficiency of natural resources and inputs, increase the grain yield, reduce production costs and reduce negative environmental impacts in FLOODE areas, the use of integrated crop management is fundamental. When the rice straw is burned, the organic matter is oxidized, and $\mathrm{CO}_{2}$ and other gases are released into the atmosphere (Santos et al. 2017). In addition, rice straw contains other nutrients, such as $\mathrm{P}, \mathrm{K}$, and $\mathrm{S}$, that may be significantly lost due to burning, as they form compounds that can be volatilized to other locations, impoverishing the area. Thus, other options should be used other than burning.

The incorporation of rice straw accelerates its decomposition, and the use of soil preparation machines and equipment for soybean cultivation can incorporate the rice straw while also correcting the soil surface roughness (Sosbai 2016). However, Knoblauch et al. (2014) report that the incorporation of rice straw in the soil should be carried out at least 30 days before sowing another crop in succession. This could make this operation unfeasible due to the narrow space of time before the soybean sowing. Silva et al. (2012) reported that the use of the kniferoller is an interesting alternative for subtropical conditions, with changes in the soil quality and a faster operation. In addition, the combined use of straw spreaders with knife-rollers and harrows should be studied. However, despite the importance of the succession of rice-soybean crops in FLOODE areas, studies on alternative rice straw management in tropical conditions are still scarce, avoiding the burning of this straw and providing agility in the soybean sowing process.

In the tropical region, a relatively high energy demand is required for soil management after harvesting the rice to make the area suitable for growing the succession crop, since the proper management is based on plowing, harrowing and leveling the soil (Sosbai 2016). Thus, this study aimed to evaluate the combination of configurations of a rice harvester and other operations on the operational and energy demand to manage the rice straw, soil roughness and vegetation cover for the soybean cultivation in succession.

\section{MATERIAL AND METHODS}

The trials were carried out at the Fazenda Sementes Talismã, in Formoso do Araguaia, Tocantins state, Brazil (11 ${ }^{\circ} 49^{\prime} 38.11^{\prime \prime S}, 49^{\circ} 38^{\prime} 02.07^{\prime \prime} \mathrm{W}$ and average altitude of $192 \mathrm{~m}$ ). The soil is classified as a thermic Typic Haplorthox (Santos et al. 2018) and the climate as wet tropical Savannah, according to the Köppen classification (Alvares et al. 2013). Thus, there are two well-defined seasons: a normally dry season from May to September (autumn/winter) and a rainy season from October to April (spring/summer).

To evaluate the appropriate rice straw management strategies, three experiments were carried out: two in 2016 and one in 2017. The first experiment consisted in determining the operational performance of a rice harvester with and without the straw spreader, in 2016. For this, a straw spreader and a diesel fuel consumption meter were installed in the harvester. The experimental design was completely randomized, with 12 replicates. The fuel consumption, effective operating speed and effective working capacity were measured.

The second experiment was conducted to verify the performance of the tractor and knife-roller assemblage, in the first and second rolling operations, in areas with rice straw piles or straw spread by the self-propelled harvester. A second rolling was evaluated, as it is sometimes required for the soil preparation. A completely randomized experimental design, in a split-plot scheme, with nine replications, 
was used. The plots and subplots were positioned in the longitudinal and perpendicular directions of the harvester, respectively. This perpendicular positioning, which is the same way that farmers use, allowed to standardize the straw amounts between subplots in the research area. Treatments to distribute the straw by the harvester, piled or spread, were applied in the plots. In the subplots, rolling operations (one and two knife-roller operations) occurred. The fuel consumption, effective operating speed, effective working capacity and skidding of the tractor and knife-roller assemblage were evaluated.

In the third experiment, the performance of the tractor and light harrowing were evaluated during the first, second and third harvesting operations (secondary operations), in areas harvested by the self-propelled harvester equipped with rice straw spreader and managed with a knife-roller (once and twice) and by the intermediate harrow once (primary managements). The experimental design was a split-plot scheme, with six replications. The primary management was applied in the plots and the secondary management in the subplots. The fuel consumption, effective operating speed, working capacity, skidding of the tractor wheels with traction of the light harrow, intermediate harrow and kniferoller, as well as the final soil surface roughness, were evaluated. The analysis of each light harrowing operation was performed on the different primary managements, using the fuel consumption data, effective operating speed, effective working capacity and skidding of the tractor wheels. The analysis of the soil management systems considered the primary and secondary joint operations, fuel consumption data, effective working capacity and soil surface roughness.

To perform the trials, the following equipments were employed: 1) self-propelled harvester with power of $133 \mathrm{~kW}$ at 2,200 rpm and cutting platform of 5,490 $\mathrm{mm}$, according to the manufacturer's specification; 2) straw spreader device added to the harvester to distribute the rice plant residues in the harvested area, with six 800-mm-long rubber blades mounted on two rotors; 3 ) tractor with front auxiliary traction of $127 \mathrm{~kW}$ at 2,200 rpm; 4) intermediate harrow with two disc sections, arranged at a 32 degree angle, with effective operating width of $3,100 \mathrm{~mm}$, containing 24 discs with $600 \mathrm{~mm}$ of diameter; 5) light harrow with two disc sections, arranged at an angle of 30 degrees, with effective operating width of 3,900 mm, containing 48 discs with $483 \mathrm{~mm}$ in diameter and 3,000 mm long; 6) a $750 \mathrm{~mm}$ diameter knife-roller with 30 knives $(1,000 \mathrm{~mm} \times 100 \mathrm{~mm})$.

In the experiments, a fuel consumption meter, profilometer, oil density meter with a scale of 0.800 $0.850 \mathrm{~g} \mathrm{~mL}^{-1}$, stopwatch and thermometer were also used. The self-propelled harvester and tractor were equipped with new tires, and the harvester had duplicate tires on the drive wheels. The sixth gear of the tractor was used in rolling operations with the knife-roller and plowing with the intermediate harrow. The seventh gear was used in the plowing operation with the light harrow. As standardization, the motor rotation of the tractor was maintained at 2,000 rpm for all performed operations. The speeds were treated as variables and their values are found in the result and discussion tables.

The experiments were conducted at and after the harvest of irrigated rice (IRGA 424 cultivar), presenting an average yield of 7,200 kg ha-1 and $6,400 \mathrm{~kg} \mathrm{ha}^{-1}$, respectively in 2016 and 2017. The experiments involving the use of the self-propelled rice harvester and the knife-roller were carried out in a water depth of about $150 \mathrm{~mm}$ in the area, and the other experiments with harrowing operations where the soil was drained. The use of the knife-roller with flooded soil is a common practice used to improve the incorporation of crop residues and soil leveling (Silva et al. 2012). All experimental plots were $50 \mathrm{~m}$ long and had a variable width, equivalent to the operating width of the equipment used. Thus, the effective widths of the plots were $5.49 \mathrm{~m}, 3.0 \mathrm{~m}, 3.1 \mathrm{~m}$ and $4.6 \mathrm{~m}$, respectively for the experiments with the selfpropelled harvester, knife-roller, intermediate harrow and light harrow.

The fuel consumption was measured during the movement of the harvester and the tractor in the experimental plots, using precision equipment built according to recommendations by Maziero et al. (1992), linked to the fuel system of the machines. The diesel temperature and density were measured in samples collected from the fuel in the return line from the injection pump to the equipment reservoir and served to convert the volume consumed to $20^{\circ} \mathrm{C}$ (Brasil 1970). The consumption values were adjusted to $\mathrm{kg} \mathrm{ha}^{-1}$, using the equation: $\mathrm{Fc}=(0.2 * \mathrm{Fp} . \mathrm{D}) / \mathrm{W}$, where: $\mathrm{Fc}$ is the fuel consumption $\left(\mathrm{kg} \mathrm{ha}^{-1}\right)$; Fp the fuel consumption in the plot ( $\left.\mathrm{mL} 50 \mathrm{~m}^{-1}\right)$; D the Diesel oil density during the operation $\left(\mathrm{g} \mathrm{cm}^{-3}\right)$; and $\mathrm{W}$ the effective width of the equipment operation (m). 
The effective operating speed (EOS, $\mathrm{km} \mathrm{h}^{-1}$ ) was estimated with the time required by the equipment to cover the space of $50 \mathrm{~m}$ in each plot: $\mathrm{EOS}=$ $(\mathrm{S} * 3.6) / \mathrm{Tc}$, where: $\mathrm{S}$ is the space travelled by the equipment in the plot $(\mathrm{m})$; and $\mathrm{Tc}$ the time (s) for the tractor with load to travel $50 \mathrm{~m}$ in the plot. With the operating speed, it is possible to calculate the effective working capacity $\left(\mathrm{Ew}, \mathrm{ha}^{-1}\right): \mathrm{Ew}=(\mathrm{EOS} *$ W) $/ 10$.

The skidding of the tractor's driving wheels (Sk, \%) was calculated considering the time required by the tractor with load to go through each experimental plot and the average time to travel the same distance on a road without pulling other equipment: $\mathrm{Sk}=[(\mathrm{Tl}-\mathrm{Twl}) / \mathrm{Tl}]$. 100, where: $\mathrm{Tl}$ is the time (s) for the loaded tractor run $50 \mathrm{~m}$ in the plot; and Twl the time (s) for the tractor without load run $50 \mathrm{~m}$ on the road.

The soil surface roughness was estimated using a profilometer with 40 rods, spaced $50 \mathrm{~mm}$ apart, installed on a rod, supported by feet at the ends. The profilometer, in the form of a comb, was installed transversally in the center of each experimental plot, after the horizontal leveling of the rod. The distances (in millimeters) from the rod to the soil surface were measured on each rod. The values obtained were used to calculate the standard deviation of the population mean, considered as the soil surface roughness index.

The data from each experiment were submitted independently to analysis of variance and, when necessary, the Tukey averages comparative test was performed $(\mathrm{p}<0.05)$. In addition, in the experiments with two levels per factor, the $t$ test was performed $(p<0.05)$. The SAS statistical software was used.

\section{RESULTS AND DISCUSSION}

The use of the straw spreader did not interfere in the operational performance of the self-propelled harvester on the irrigated rice harvest (Table 1). This indicates that the presence of the spreader did not affect the working speed and operating efficiency, and did not increase the fuel consumption.

The uniform straw distribution on the ground after the rice harvest facilitates the planting of the successive crop, protects the soil against rain and sun, and reduces the cost of the next sowing. On the other hand, the straw left on the ground interferes in the soil preparation and in the following sowing operations, clogging the equipment and reducing the germination percentage and crop stand (Silva 2013).

The second pass of the knife-roller showed differences in the working capacity, fuel consumption and wheel skidding, in relation to the first rolling in the same area (Table 2). Soil and straw management operations, after harvesting the rice, are difficult due to the deep tracks left in the soil by the self-propelled harvester and because of the large amount of straw left in the area. Thus, each operation presents its specificity. The first rolling is usually more difficult to perform on the more uneven ground, which may require a second operation (Theisen et al. 2017). The irregularity in the area caused instability of the tractor and increased the skidding of the tractor's driving wheels. This negatively interfered with the operating speed and, therefore, with the working capacity of the tractor and knife-roller assemblage, as well as with the fuel consumption, if compared to the second rolling operation. On the other hand, the operation of distributing the rice straw during the harvest with a self-propelled harvester, in relation to the operation in which the straw was piled, favored the rolling and significantly improved the performance of the operation parameters of working capacity and skidding of the driving wheels. The fuel consumption in the rolling operation on spread and piled straw was similar. Thus, based on the experiment 1 , because the operation of distributing the straw does not increase the fuel consumption and this operation improves the workability parameters and reduces the skidding

Table 1. Operating speed, fuel consumption and working capacity of a self-propelled harvester, with and without straw spreaders, in the rice harvest.

\begin{tabular}{lccc}
\hline \multicolumn{1}{c}{ Treatment } & Fuel consumption $\left(\mathrm{kg} \mathrm{ha}^{-1}\right)$ & Operating speed $\left(\mathrm{km} \mathrm{h}^{-1}\right)$ & Working capacity $\left(\mathrm{h} \mathrm{ha} \mathrm{H}^{-1}\right)$ \\
\hline With straw spreader & $17.83 \mathrm{a}^{*}$ & $2.31 \mathrm{a}$ & $0.78 \mathrm{a}$ \\
Without straw spreader & $17.33 \mathrm{a}$ & $2.35 \mathrm{a}$ & $0.77 \mathrm{a}$ \\
\hline Average & 17.60 & 2.33 & 0.78 \\
\hline CV $(\%)$ & 4.68 & 3.57 & 3.67 \\
\hline
\end{tabular}

* Averages followed by the same lowercase letter in the column do not differ by the t-test $(\mathrm{p}<0.05)$. CV: coefficient of variation. 
Table 2. Tractor and knife-roller performance in the first and second rolling operations, in floodplain areas, with rice straw spread or piled by a self-propelled harvester during harvesting.

\begin{tabular}{lcccc}
\hline \multicolumn{1}{c}{ Treatment } & Fuel consumption $\left(\mathrm{kg} \mathrm{ha}^{-1}\right)$ & Operating speed $\left(\mathrm{km} \mathrm{h}^{-1}\right)$ & Working capacity $\left(\mathrm{h} \mathrm{ha}^{-1}\right)$ & Skidding (\%) \\
\hline Knife-roller & & & & \\
1st operation & $11.20 \mathrm{~b}^{*}$ & $5.24 \mathrm{a}$ & $0.64 \mathrm{~b}$ & $18.67 \mathrm{~b}$ \\
2nd operation & $10.03 \mathrm{a}$ & $5.93 \mathrm{~b}$ & $0.56 \mathrm{a}$ & $17.41 \mathrm{a}$ \\
\hline Straw distribution & & & & \\
Spread & $10.73 \mathrm{a}$ & $5.66 \mathrm{~b}$ & $0.59 \mathrm{a}$ & $17.52 \mathrm{a}$ \\
Piled & $10.50 \mathrm{a}$ & $5.52 \mathrm{a}$ & $0.61 \mathrm{~b}$ & $18.56 \mathrm{~b}$ \\
\hline Average & 10.62 & 5.59 & 0.60 & 18.05 \\
\hline $\mathrm{CV}(\%)$ & 8.89 & 3.16 & 3.11 & 7.33 \\
\hline * Averages followed by the same lowercase letter in the column do not differ by the t-test $(\mathrm{p}<0.05)$. CV: coefficient of variation.
\end{tabular}

* Averages followed by the same lowercase letter in the column do not differ by the t-test $(\mathrm{p}<0.05)$. CV: coefficient of variation.

(experiment 2), the use of a straw spreader on the rice harvester is recommended.

The percentage of skidding of the tractor's driving wheels increased with the increase of the harrowing operations (Table 3 ). Usually this occurs because the harrow tends to penetrate more into the soil as the operations in the same area are repeated, what demands more effort from the tractor in the operation (Silva 2013). The demand for more tractor power also results in a higher fuel consumption (Yanai et al. 1999, Hamzei \& Seyyedi 2016, Theisen et al. 2017). This fact was evident in this experimentation about the specific fuel demand, which increased with the repetition of the harvesting operation. The third harrowing operation required more fuel for its performance and differed statistically from the other harrowings. The working capacity of the light harrow significantly differs according to the order of accomplishment. The first light harrowing required less operating time than the following harrowings.

The light harrow had a lower performance when operated after the intermediate harrow, if compared to the knife-roller (Table 3). The plowing treatments were applied to the plots at 60 days after the rolling treatments, because the plowing demands a friable soil, and the roller performs better with water. Thus, during the light harrowing, the plowed soil particles were more disaggregated than in the rolled soil. This probably resulted in a greater penetration of the light harrow into the plowed soil, resulting in a greater tractor skidding, fuel consumption and operating time. The light harrowing done after a rolling operation had a lower percentage of tractor skidding, operating time and fuel consumption than the other treatments.

There was interaction between the primary and secondary management for fuel consumption (Table 4). Therefore, the soil and rice straw management systems combining the use of the knife-roller or the intermediate harrow with the light harrow required different amounts of fuel. The lowest consumption was $16.40 \mathrm{~kg} \mathrm{ha}^{-1}$ for the combination of one rolling with one light harrowing, and the highest consumption was $34.10 \mathrm{~kg} \mathrm{ha}^{-1}$ for the system with two rollings and three light harrowings. The fuel consumption increases with the number of operations performed and with the type of implement used (Silva 2013). Therefore, the amount of equipment operations should be the

Table 3. Tractor and light harrow performance in the first, second and third harrowing operations, in a flooded rice field managed with knife-rollers and intermediate harrows.

\begin{tabular}{|c|c|c|c|}
\hline Treatment & Fuel consumption $\left(\mathrm{kg} \mathrm{ha}^{-1}\right)$ & Working capacity $\left(\mathrm{h} \mathrm{ha}^{-1}\right)$ & Skidding $(\%)$ \\
\hline Light harrow 1st operation & $4.34 \mathrm{a}^{*}$ & $0.29 \mathrm{a}$ & $11.36 \mathrm{a}$ \\
\hline Light harrow 2 nd operation & $4.40 \mathrm{a}$ & $0.30 \mathrm{~b}$ & $12.55 \mathrm{~b}$ \\
\hline Light harrow 3rd operation & $4.64 \mathrm{~b}$ & $0.30 \mathrm{~b}$ & $13.83 \mathrm{c}$ \\
\hline Light harrow after 1 knife-roller operation & $4.34 \mathrm{a}$ & $0.29 \mathrm{a}$ & $10.30 \mathrm{a}$ \\
\hline Light harrow after 2 knife-roller operations & $4.47 \mathrm{~b}$ & $0.30 \mathrm{~b}$ & $12.90 \mathrm{~b}$ \\
\hline Light harrow after 1 intermediate harrowing operation & $4.60 \mathrm{~b}$ & $0.31 \mathrm{c}$ & $14.54 \mathrm{c}$ \\
\hline Average & 4.46 & 0.30 & 12.58 \\
\hline $\mathrm{CV}(\%)$ & 5.51 & 2.31 & 12.82 \\
\hline
\end{tabular}

*Averages followed by the same lowercase letter in the column do not differ by the Tukey test $(\mathrm{p}<0.05)$. CV: coefficient of variation. 
Table 4. Fuel consumption $\left(\mathrm{kg} \mathrm{ha}^{-1}\right)$ of the tractor-implement assemblage, as a function of the soil management systems, in floodplain areas with rice straw spread by the self-propelled harvester during harvesting.

\begin{tabular}{lcccc}
\hline \multirow{2}{*}{ Primary management } & \multicolumn{4}{c}{ Secondary management } \\
\cline { 2 - 5 } & Light harrowing (once) & Light harrowing (twice) & Light harrowing (three times) & Average \\
\hline Knife-roller (once) & $16.35 \mathrm{Cb}^{*}$ & $20.01 \mathrm{Bc}$ & $24.23 \mathrm{Ac}$ & $20.20 \mathrm{c}$ \\
Knife-roller (twice) & $26.48 \mathrm{Ca}$ & $29.60 \mathrm{Ba}$ & $34.09 \mathrm{Aa}$ & $30.06 \mathrm{a}$ \\
Intermediate harrow (once) & $16.77 \mathrm{Cb}$ & $24.19 \mathrm{Bb}$ & $30.26 \mathrm{Ab}$ & $23.74 \mathrm{~b}$ \\
\hline Average & $19.86 \mathrm{C}$ & $24.60 \mathrm{~B}$ & $\mathrm{~A}$ & 24.67 \\
\hline CV $(\%)$ & 3.99 & & & \\
\hline
\end{tabular}

* Averages followed by the same lowercase letter in the column and uppercase letter in the row do not differ by the Tukey test (p $<0.05)$. CV: coefficient of variation.

minimum necessary to leave the soil well managed for allowing the proper installation and handling of the successive crop. The management of soil and rice straw have generally been done with a knife-roller and two harrows or by one intermediate harrow and up to three light harrows (Santos et al. 2017, Theisen et al. 2017). Considering these two management systems, the fuel demand verified in this experiment for the rolling system was equivalent to $66 \%$ of the harrowing system.

The results also indicate the relation between the studied management systems (Table 4). Rollingbased systems required less fuel consumption than the others, based on two rolls or one harrowing. However, the differences in consumption were only statistically significant when the management systems were configured with two or three light harrowing operations.

There was interaction between primary and secondary management for the working capacity (Table 5). So, the time demanded for the soil and rice straw management systems ranged from $0.77 \mathrm{~h} \mathrm{ha}^{-1}$ in the configuration with one roll plus one light harrow to $1.81 \mathrm{~h} \mathrm{ha}^{-1}$ in the configuration with two rolls plus three light harrows. As verified for fuel consumption, there was a relationship between the primary management made with a knife-roller or one harrow and the secondary management based on light harrow, in the analysis of work capacity.

The management systems based on rolling demanded a significantly shorter operating time than the other studied systems, except for the one formed by the intermediate harrowing followed by a light harrowing, which demanded a statistically similar operating time. In the evaluations of the primary managements combined with each secondary management, a greater work capacity of the harrowing system was expected, since the harrow had a width superior to the knife-roller by $0.1 \mathrm{~m}$. Both equipments were operated at the same engine and tractor speed. This was due to the reduction in the operating speed probably caused by the increased skidding of the tractor's wheels when pulling the harrow. However, the systems with rolling stood out, since, besides demanding less operational time, they can be performed regardless of climatic conditions and even in the presence of rain, what makes this system more advantageous, especially in relation to the system based on harrowing that must be done on friable soil.

There was no interaction between primary and secondary management for the soil surface roughness index (Table 6). Therefore, all primary management systems with two or three light harrowings significantly

Table 5. Working capacity $\left(\mathrm{h} \mathrm{ha}^{-1}\right)$ of the tractor-implement assemblage, as a function of the soil management systems, in irrigated rice area harvested with a self-propelled harvester with a straw spreader.

\begin{tabular}{lcccc}
\hline \multirow{2}{*}{ Primary management } & \multicolumn{4}{c}{ Secondary management } \\
\cline { 2 - 5 } & Light harrowing (once) & Light harrowing (twice) & Light harrowing (three times) & Average \\
\hline Knife-roller (once) & $0.77 \mathrm{Aa}^{*}$ & $1.07 \mathrm{Ba}$ & $1.38 \mathrm{Ca}$ & $1.07 \mathrm{a}$ \\
Knife-roller (twice) & $1.22 \mathrm{Ab}$ & $1.50 \mathrm{Bc}$ & $1.81 \mathrm{Cc}$ & $1.51 \mathrm{c}$ \\
Intermediate harrow (once) & $0.78 \mathrm{Aa}$ & $1.10 \mathrm{Bb}$ & $1.42 \mathrm{Cb}$ & $1.10 \mathrm{~b}$ \\
\hline Average & $0.92 \mathrm{~A}$ & $1.22 \mathrm{~B}$ & $1.53 \mathrm{C}$ & 1.19 \\
\hline $\mathrm{CV}(\%)$ & 1.19 & & & \\
\hline
\end{tabular}


Table 6. Soil surface roughness index, as a function of area management systems of irrigated rice harvested with a self-propelled harvester.

\begin{tabular}{lcccc}
\hline \multirow{2}{*}{ Primary management } & \multicolumn{4}{c}{ Secondary management } \\
\cline { 2 - 5 } & Light harrowing (once) & Light harrowing (twice) & Light harrowing (three times) & Average \\
\hline Knife-roller (once) & $4.52 \mathrm{Aa}^{*}$ & $3.42 \mathrm{Ba}$ & $2.89 \mathrm{Ba}$ & $3.61 \mathrm{a}$ \\
Knife-roller (twice) & $4.22 \mathrm{Aa}$ & $3.15 \mathrm{Ba}$ & $3.37 \mathrm{Ba}$ & $3.58 \mathrm{a}$ \\
Intermediate harrow (once) & $4.59 \mathrm{Aa}$ & $3.85 \mathrm{Ba}$ & $3.25 \mathrm{Ba}$ & $3.90 \mathrm{a}$ \\
\hline Average & $4.44 \mathrm{~A}$ & $3.47 \mathrm{~B}$ & $3.17 \mathrm{~B}$ & \\
\hline CV $(\%)$ & 13.90 & & & 3.69 \\
\hline * Averages followed by the same lowercase letter in the column and uppercase letter in the row do not differ by the Tukey test $(\mathrm{p}<0.05)$. CV: coefficient of variation.
\end{tabular}

reduced the soil surface roughness index, relatively to the system with only one light harrowing (Table 6). The addition of a third light harrowing operation did not improve the soil surface roughness and is therefore expendable, reducing the cost of the operation. The primary management of soil and rice straw did not influence the soil roughness index and, therefore, the system with lower operating time, less fuel consumption and ease accomplishment with the climate and soil moisture should be preferred.

Rice-soybean rotation is used in several lowland cultivation systems in the world (Theisen et al. 2017). The constraints associated with the presence of rice straw on the adequate formation of the soybean crop stand are well known in these hydromorphic soils (Garrity \& Gines 1990, Santos et al. 2017). Soybean requires an efficient soil drainage system and adequate management of previously cultivated rice straw to provide high seed germination rates, adequate seedling survival and good plant development (Wuebker et al. 2001). In this sense, based on the results obtained in the three experiments, the system of soil and rice straw management conducted with the straw spreader coupled to the harvester, one rolling with knife-roller and two light harrowings is the most appropriate to prepare the ground after the cultivation of rice to plant soybean, as this system presents the best combination of technical and energy performance. Trials with soybean sowing should be done to confirm this.

\section{CONCLUSIONS}

1. The energy costs in harvesting rice do not rise when the self-propelled harvester operates with a spreader to distribute the straw on the ground and to avoid the formation of straw piles;

2. The piled rice plant residues increases the skidding of the tractor when pulling the knife-roller, with a consequent reduction of the operating speed and elevation of the working capacity, but this does not affect the fuel consumption;

3. The increase in the number of light harrowings, from one to two operations, in areas worked with a knife-roller or with intermediate harrow, requires more time and fuel in the management of the soil and rice straw, but leaves the ground with the least surface roughness;

4. The rice straw management system with a kniferoller coupled with a harvester and two light harrows provides the best straw distribution, least ground roughness and low energy expenditure.

\section{REFERENCES}

ALVARES, C. L. et al. Köppen's climate classification map of Brazil. Meteorologische Zeitschrift, v. 22, n. 6, p. 711-728, 2013.

BRASIL. Conselho Nacional do Petróleo. Resolução CNP $\mathrm{n}^{\mathrm{o}} 6$, de 25 de junho de 1970. Aprova novas tabelas de coeficientes para correção da densidade e do volume dos derivados de petróleo. Diário Oficial da União, Brasília, DF, 13 Jul. 1970. p. 1521a.

COELHO, M. R. et al. Solos. In: SANTOS, A. B.; STONE, L. F.; VIERA, N. R. A. (Eds.). A Cultura do arroz no Brasil. Santo Antônio de Goiás: Embrapa, 2006. p. 161208.

COMPANHIA NACIONAL DE ABASTECIMENTO (Conab). Boletim da safra de grãos. 2018. Available at: <https://www.conab.gov.br/info-agro/safras/graos>. Access on: 20 Aug. 2018.

FRAGOSO, D. B. et al. Caracterização e diagnóstico da cadeia produtiva do arroz no estado do Tocantins. Brasília, DF: Embrapa, 2013.

GARRITY, D. P.; GINES, H. C. The development of rice-corn rotations in tropical lowland environments: a systems research approach. Taipei: Food and Fertilizer Technology Center, 1990. (Extension bulletim, 318). 
HAMZEI, J.; SEYYEDI, M. Energy use and input-output costs for sunflower production in sole and intercropping with soybean under different tillage systems. Soil \& Tillage Research, v. 157, n. 1, p. 73-82, 2016.

KNOBLAUCH, R. et al. Rice straw incorporated just before soil flooding increases acetic acid formation and decreases available nitrogen. Revista Brasileira de Ciência do Solo, v. 38, n. 1, p. 177-184, 2014.

MAZIERO, J. V. G. et al. Equipamento para medição do consumo de combustível em experimentos agrícolas. Bragantia, v. 51, n. 2, p. 197-202, 1992.

PELÚZIO, J. M. et al. Comportamento de cultivares de soja sob condições de várzea irrigada no sul do estado do Tocantins: entressafra 2005. Bioscience Journal, v. 24, n. 1, p. 75-80, 2008.

SANTOS, A. B. et al. Uso do rolo-faca na eliminação da queima da palha de arroz em área de produção irrigada no Tocantins. In: CONGRESSO BRASILEIRO DE ARROZ IRRIGADO, 10., 2017, Gramado. Anais... Gramado: Sosbai, 2017. p. 1-4.

SANTOS, A. B.; STONE, L. F.; VIEIRA, N. R. A. $A$ cultura do arroz no Brasil. 2. ed. Santo Antônio de Goiás: Embrapa Arroz e Feijão, 2006.
SANTOS, H. G. et al. Sistema brasileiro de classificação de solos. 5. ed. Rio de Janeiro: Centro Nacional de Pesquisa de Solos, 2018.

SILVA, J. G. Arroz: mecanização. A Lavoura, n. 695, p. 15-19, 2013.

SILVA, J. J. C. et al. Avaliação do uso de rolo-faca no preparo do solo pós-colheita do arroz irrigado em área da planície costeira do RS. Pelotas: Embrapa Clima Temperado, 2012. (Documentos, 349).

SOCIEDADE SUL-BRASILEIRA DE ARROZ IRRIGADO (Sosbai). Arroz irrigado: recomendações técnicas da pesquisa para o Sul do Brasil. Pelotas: Sosbai, 2016.

THEISEN, Y. G.; SILVA, J. C. C.; BASTIANS, L. A kniferoller effectively substitutes soil preparation by ploughand-harrow in lowland production systems. Experimental Agriculture, v. 54, n. 6, p. 1-14, 2017.

WUEBKER, E. F.; MULLEN, R. E.; KOEHLER, K. Flooding and temperature effects on soybean germination. Crop Science, v. 41, n. 6, p. 1857-1861, 2001.

YANAI, K. et al. Desempenho operacional de trator com e sem o acionamento da tração dianteira auxiliar. Pesquisa Agropecuária Brasileira, v. 34, n. 8, p. 1427-1434, 1999. 